\title{
Interleukin 18 in the CNS
}

\author{
Silvia Alboni ${ }^{1 \dagger}$, Davide Cervia ${ }^{2 \dagger}$, Shuei Sugama ${ }^{3}$, Bruno Conti ${ }^{4^{*}}$
}

\begin{abstract}
Interleukin (IL)-18 is a cytokine isolated as an important modulator of immune responses and subsequently shown to be pleiotropic. IL-18 and its receptors are expressed in the central nervous system (CNS) where they participate in neuroinflammatory/neurodegenerative processes but also influence homeostasis and behavior. Work on IL-18 null mice, the localization of the IL-18 receptor complex in neurons and the neuronal expression of decoy isoforms of the receptor subunits are beginning to reveal the complexity and the significance of the IL-18 system in the CNS. This review summarizes current knowledge on the central role of IL-18 in health and disease.
\end{abstract}

\section{Introduction}

Interleukin (IL)-18 was isolated in 1995 as a co-factor that, in synergism with IL-12, stimulated the production of gamma interferon (INF- $\gamma$ ) in Th1 cells [1]. Since then extensive in vitro and in vivo studies have identified IL18 as an important link between innate and adaptive immune responses and a regulator of both cellular and humoral immunity [2-4]. Constitutively produced as an inactive precursor by several cell types IL-18 is secreted in its active form following maturation by caspase 1 in response to inflammatory and infectious stimuli. In addition to its effects on Th1 cells, IL-18 is a strong stimulator of the activity of natural killer cells alone or in combination with IL-15, and of $\mathrm{CD}^{+}$lymphocytes. Together with IL-2, IL-18 can also stimulate the production of IL-13 and of other Th2 cytokines. Thus, it is perhaps not surprising that IL-18 was found to be associated with or demonstrated to contribute to numerous inflammatory-associated disorders. These include infections, autoimmune diseases, rheumatoid arthritis, cancer, as well as metabolic syndrome and atherosclerosis [5-11].

IL-18 had not originally been expected to cross an intact blood brain barrier and its immunological effector cells are not normally found in the healthy brain. Yet, studies on the possible role of IL-18 in the central nervous system (CNS), initiated soon after its cloning, were prompted primarily by its similarities with IL-1, which was already demonstrated to have central action. It was

\footnotetext{
* Correspondence: bconti@scripps.edu

+ Contributed equally

${ }^{4}$ Molecular and Integrative Neurosciences Department, The Scripps Research Institute, CA, USA
}

soon found that IL-18 could be synthesized centrally and its receptor subunits were now demonstrated to be broadly expressed in neurons. When recombinant interleukin 18 became available it also became clear that IL18 was active centrally. Work on mice null for IL-18 or its receptor subunit alpha is helping to decipher the action of this cytokine in the brain. Finally, the recent discovery of novel IL-18 receptor subunits in the brain has revealed the complexity of the IL- 18 system and may lead to better understanding of both the similarities and opposing actions of IL-1 and IL-18. This review summarizes more than a decade of work aimed at understanding how the IL-18 system contributes to local central inflammatory processes or can influence neuronal function and behavior. A summary of the literature supporting the involvement of IL-18 in neurophysiological and neuropathological conditions is presented in Table 1.

\section{Components of the IL-18 system}

IL-18 is synthesized as an inactive $24-\mathrm{kDa}$ precursor protein that is subsequently processed by caspase- 1 into its mature secretable form, which has a molecular weight of $18 \mathrm{kDa}$ [4,12-16]. Pro-IL-18 can also be processed into its active form by various extracellular enzymes including protease 3 (PR-3), serine protease, elastase and cathepsin G [17-19]. Only the mature peptide is reported to be biologically active.

The existence of a putative short isoform of IL-18 resulting from alternative splicing removing $57 \mathrm{bp} / 19$ aa was first described in rat adrenal glands (IL-18 $\alpha$ ) [20] and subsequently in mouse spleens (IL-18s) [21]. Recombinant IL-18s did not display IL-18-like activity in stimulating INF- $\gamma$ production when tested alone but appeared 

Table 1 Representative neurophisiological and
neurophatological conditions involving IL-18

\begin{tabular}{lll}
\hline Condition & Species & Citation \\
\hline Behavior & & \\
\hline Sleep & Rat/Rabbit & {$[72]$} \\
Fever & Mouse & {$[73,162]$} \\
Feeding & Mouse & {$[10,11]$} \\
Learning and memory & Mouse & {$[77]$} \\
& Rat & {$[48,74,75]$} \\
& Human & {$[108,111,163]$} \\
\hline Stress and HPA axis & & \\
\hline & Rat & {$[56,57,81]$} \\
& Rat/Mouse & {$[62]$} \\
& Holstein cattle & {$[80]$} \\
& Pig & {$[54,55]$} \\
& Human & {$[136]$} \\
\hline
\end{tabular}

\begin{tabular}{|c|c|c|}
\hline \multicolumn{3}{|l|}{ Neuroinflammation } \\
\hline \multicolumn{3}{|l|}{ Brain injury } \\
\hline \multirow[t]{2}{*}{ Hypoxia-ischemia } & Mouse & {$[67,84,164-167]$} \\
\hline & Rat & {$[67,168]$} \\
\hline Thromboembolic stroke & Mouse & [83] \\
\hline Spinal cord injury & Rat & [87] \\
\hline Focal brain ischemia & Rat & {$[86]$} \\
\hline \multirow[t]{2}{*}{ Stroke } & Mouse & {$[59,85]$} \\
\hline & Human & [169] \\
\hline Nerve injury & Rat & {$[47]$} \\
\hline \multirow[t]{2}{*}{ Viral infection } & Chicken & {$[170]$} \\
\hline & Human & {$[59,171]$} \\
\hline \multicolumn{3}{|c|}{ Autoimmune neurodegenerative disease } \\
\hline Multiple Sclerosis & Human & {$[95-99,101]$} \\
\hline \multirow[t]{2}{*}{ EAE } & Mouse & {$[91,93,100]$} \\
\hline & Rat & {$[89,90,92,94]$} \\
\hline \multicolumn{3}{|l|}{ Neurodegenerative disease } \\
\hline Alzheimer's disease & Human & {$[50,106-109,111-114]$} \\
\hline Parkinson's disease & Mouse & {$[117]$} \\
\hline \multicolumn{3}{|l|}{ Neuropsychiatric disorders } \\
\hline \multirow[t]{2}{*}{ Depression } & Rat & [133] \\
\hline & Human & {$[136,137,139]$} \\
\hline Schizophrenia & Human & {$[134,135]$} \\
\hline \multicolumn{3}{|l|}{ Other central actions } \\
\hline \multicolumn{3}{|l|}{ Excitotoxic damage } \\
\hline Ataxia & Mouse & {$[53]$} \\
\hline Neurodegeneration & Mouse & [150] \\
\hline \multirow[t]{2}{*}{ Glioma } & Rat & {$[156,157]$} \\
\hline & Mouse & [152-155] \\
\hline
\end{tabular}

to have a modest synergistic action with IL-18. To this date this isoform has not been reported in the CNS.

The IL-18 receptor (IL-18R) belongs to the interleukin 1 receptor/Toll like receptor superfamily. It is comprised of two subunits, IL-18R $\alpha$ (also known as IL-1Rrp1, IL18R1 or IL-1R5) and IL-18R $\beta$ (also termed IL-18RacP, IL-18RII or IL-1R7) both with three extracellular immunoglobuling-like domains and one intracellular Toll/IL-1 receptor (TIR) domain [22,23]. IL-18 is believed to bind directly only to IL-18R $\alpha$ with signal transduction occurring after recruitment of IL-18R $\beta$ to form a high-affinity heterotrimeric complex with IL$18 \mathrm{R} \alpha / \mathrm{IL}-18$ [23-25].

Isoforms of both IL-18R $\alpha$ and IL-18R $\beta$ were recently described in vivo in the CNS. They include a short transcript for IL-18R $\alpha$ encoding for a receptor subunit lacking the TIR domain arbitrarily named IL-18R $\alpha$ type II [26]. Since the TIR domain is required for signaling, IL$18 \mathrm{R} \alpha$ type II was proposed to be a decoy receptor, similar to the type II IL-1R [27]. In addition, a truncated form of IL-18R $\beta$ comprising only one of the three immunoglobulin domains was described in rat and human tissues including the brain $[28,29]$. This form was proposed to act as a soluble negative regulator of IL-18 action by stabilizing IL-18 binding to IL-18R $\alpha$ yet preventing signaling.

Another negative regulator of IL-18 action is the IL-18 binding protein (IL-18BP). Isolated as cytokine-binding molecules, this $38-\mathrm{kDa}$ soluble protein displays some sequence homology with IL-18R $\alpha$ [30-32]. IL-18BP binds selectively and with high affinity to mature IL-18, but not to pro-IL-18, preventing its interaction with IL$18 \mathrm{R} \alpha$. Four human (18BPa-d) and two murine (IL$18 \mathrm{BPc}$ and d) IL-18BP isoforms have been described [33]. Of these human IL-18BPb and d lack the structural requirement to inhibit IL-18 action and their role remains to be determined [5].

A different member of the IL-1 family, IL-1F7, is also a negative regulator of IL-18 action. IL-1F7 is able to bind IL-18BP and the IL-18BP/IL-1F7 complex can interact with the IL-18R $\beta$ chain preventing the formation of the funtional IL-18R complex [34]. Several human IL-1F7 splice variants (IL-1F7a-e) have been described [35-39] whereas no murine homologue of IL1F7 has yet been found. Of these, IL-1F7b (also known as IL-1H, IL-1H4 and IL-1RP1) matured by caspase- 1 is capable of binding IL-18R $\alpha[37,40]$. Yet, the IL-1F7/IL$18 R \alpha$ complex failed to recruit IL-8R $\beta$ and no direct agonistic nor antagonistic activity of IL-1F7b for IL-18R was described $[37,40]$.

IL-18 signaling

Canonical IL-18 action occurs via recruitment of the adaptor myeloid differentiation factor (MyD88). This event allows activation of the IL-1R-associated kinase (IRAK)/tumor necrosis factor receptor-associated factor 6 (TRAF6) pathway leading to nuclear translocation of the nuclear factor kappa beta $(\mathrm{NF}-\kappa \mathrm{B})$ and subsequent modulation of gene transcription [4,5,41,42] (Fig 1).

IL-18 has also been reported to signal via the activation of the transcription factor tyk-2 [43], STAT3 [44] 
and NFATc4 [45]. In addition, a role for mitogen-activated protein kinases (MAPK) (i.e., extracellular signalregulated kinase, ERK1/2 and p38), and phosphatidylinositol-3 kinase (Pi3K) in IL-18 signalling has been suggested $[4,44-46]$.

While these data on peripheral cells were consolidated over a decade of work with the immune system, knowledge of the IL-18-dependent signaling in the CNS is only beginning to emerge. Activation of the IL-18R increased NF- $\kappa \mathrm{B}$ phosphorylation and induced hypertrophy in astrocytes [47]. In the rat dentate gyrus, the functional effects of IL-18 were significantly attenuated by prior application of c-jun-n-terminal kinase (JNK) pathway, cyclooxygenase-2 (COX-2) and inducible nitric oxide synthase (iNOS) inhibitors, and a role for p38 MAPK was also suggested $[48,49]$. Moreover, human neuron-like differentiated SH-SY5Y neuroblastomas exhibited an IL-18-dependent increase in the levels of several kinases including p35, Cdk5, GSK-3beta, and Ser15-phosphorylated p53 [50].

\section{IL-18 system in the CNS}

IL-18 transcript was demonstrated by RT-PCR in a variety of brain regions including the hippocampus, the hypothalamus and the cerebral cortex [51,52]. In in vivo

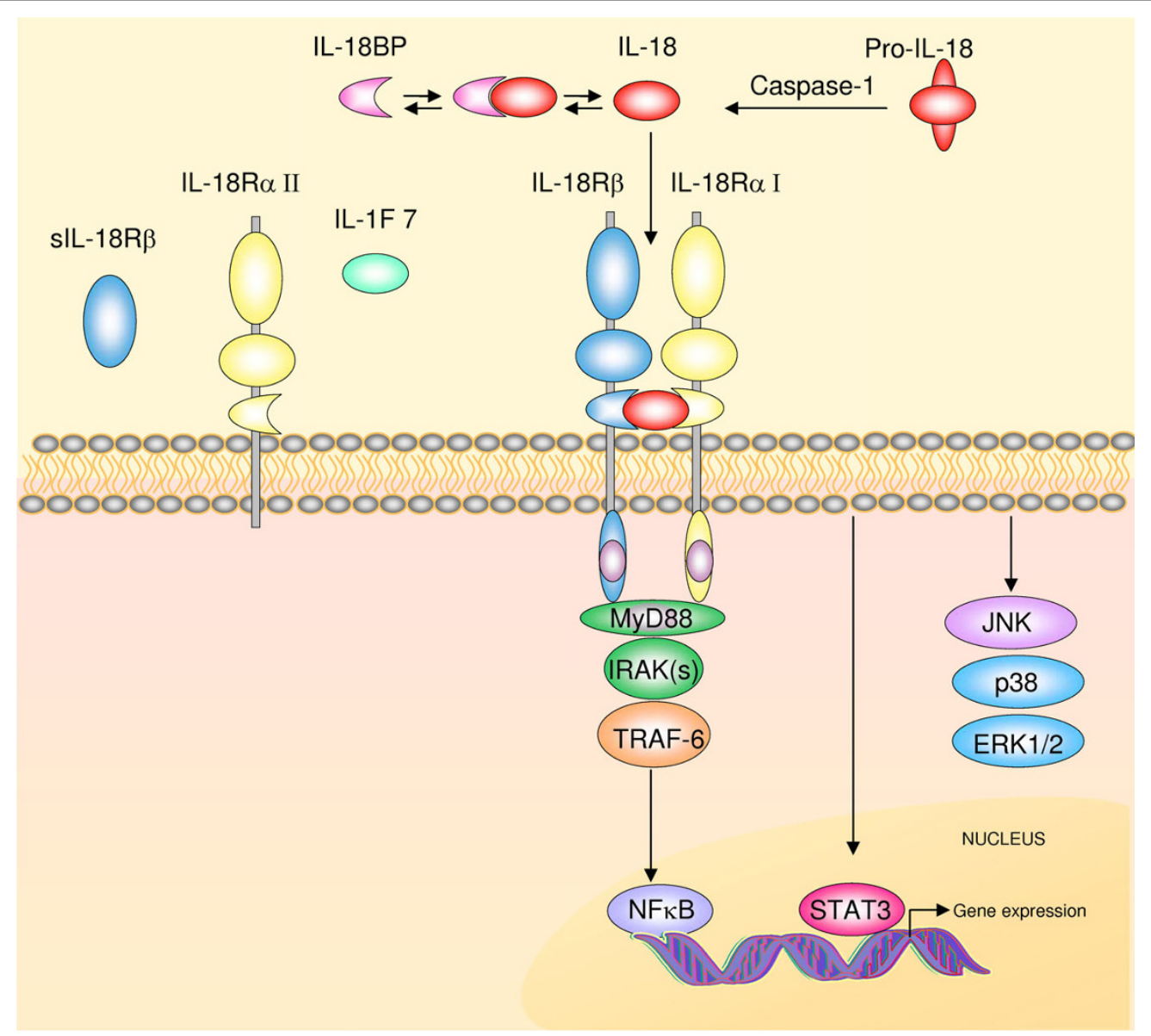

Figure 1 The IL-18 system. Active IL-18 is produced and secreted after proteolitic cleavage of the biological inactive precursor Pro-IL-18 by caspase-1. IL-18 action can be regulated by the IL-18 binding protein (IL18-BP) that binds IL-18 with high affinity and inhibits its function. Free IL-18 binds to a specific heterodimeric cell surface receptor, a member of the IL-1 receptor/Toll like receptor superfamily comprised of two subunits, IL-18R $\alpha$ (here referred to as IL-18R $\alpha$ I) and IL-18R $\beta$, both with three extracellular Ig-like domains and one intracellular portion containing the Toll/L-1R domain (TIR). Interaction of IL-18 with the IL-18R $\alpha$ stabilizes its interaction with IL-18R $\beta$ and with the adaptor protein MyD88 via the TIR domain. This initiates signal transduction by recruitment of the IL-1 receptor activating kinase (IRAK). IRAK autophosphorylates and dissociates from the receptor complex subsequently interacting with the TNFR-associated factor-6 (TRAF6) eventually leading to nuclear translocation of the nuclear factor $\kappa \mathrm{B}$ (NF- $\kappa \mathrm{B})$. Engagement of the IL-18R complex can also activate STAT3 and the mitogen-activated protein kinase (MAPK) p38, JNK and ERK. One truncated variant of IL-18R $($ (IL-18Rall) lacking the intracellular TIR domain, and one soluble isoform of the IL-18R $\beta$ (sIL-18R $\beta$ ) were demonstrated in vivo in the mouse brain and in the rat and human brain, respectively. These isoforms originating from differential splicing are proposed to be decoy receptors and possible negative regulators of IL-18 fuction. IL-1F7 is another proposed regulator of IL-18 action (see text for details). 
studies, IL-18 protein was demonstrated in the pituitary gland, ependymal cells, the neurons of the medial habenula (where its synthesis was elevated by stress), in Purkinje cells, and in astrocytes in the cerebellum [53-57]. In addition, it was demonstrated in vitro that microglia and astrocytes can produce IL-18 [58-61] and its level can be up-regulated following LPS stimulation [62] or treatment with INF- $\gamma[63]$.

In the CNS, Northern blot analysis failed to detect the presence of IL-R $\alpha$ [64] and IL-R $\beta$ [65] soon after their cloning. The first evidence that IL-18R components are expressed in brain tissue was obtained by Wheeler and colleagues [52] which reported the constitutive expression of IL-18R $\alpha$, IL-18R $\beta$ in the rat hypothalamus by RT-PCR. Subsequently, the mRNA expression of IL-18R $\alpha$, IL-18R $\beta$ and the soluble form of the IL-18R $\beta$ were detected in the hypothalamus, hippocampus, striatum and cortex and in cultured astrocytes, microglia and neurons [28]. More recently in vivo analysis showed that IL-18R $\alpha$ mRNA and protein are constitutively expresseed in neurons throughout the brain $[26,53,60,66]$. Similar neuronal localization and distribution was found for IL-18R $\beta$ (Alboni et al., unpublished data). At the same time it was demonstrated that the truncated decoy form of the IL-18R $\alpha$ was expressed in neuronal cells with a pattern similar to that of its active counterpart [26]. Overall, IL-18R subunits had broad distribution across the brain with the highest level in the hypothalamus, hippocampus and amygdala. Finally, both IL-18 and IL-18R subunits are inducible and their CNS levels can be regulated. For instance, in the mouse hippocampus the levels of IL-18 and IL-18R $\alpha$ increased after kainic acid (KA)-induced excitotoxicity, [60] whereas hypoxic-ischemic brain injury markedly increased IL18 expression in mouse microglia [67]. In addition nerve injury induced IL-18 upregulation in rat spinal cord microglia possibly via p38 activation [47].

IL-18BP has been investigated and demonstrated in rodent brains, mixed glia and microglia by only one group using RT-PCR. Its distribution and action in the CNS remain to be investigated $[52,68]$.

Information on central IL-1F7 is also limited to one study that demonstrated its presence in the human brain [37]. Investigating IL-1F7 in the CNS is also hampered by the fact that a mouse homologue has not been identified.

\section{Behavior}

The similarities between the IL- 1 and the IL-18 systems suggested the possibility that like IL-1 $\beta$, IL-18 may be one mediator of the behavior symptoms of sickness. These include fever, lethargy, hypophagia and cognitive alterations [69-71].
It was demonstrated that central intracerebroventricular (i.c.v.) injection of IL-18 in rabbits and rats increased nonrapid eye movement sleep as well as brain temperature [72]. The lethargic effects of IL-18 were also observed following intraperitoneal injection of IL-18, whereas, unlike IL-1 $\beta$, peripheral administration did not induce fever [72,73]. Instead, pre-treatment with IL-18 reduced the pyrogenic effects of IL-1 suggesting the possibility of an antagonizing effect of these cytokines on fever [73].

Work on IL-18 null, and on IL-18BP overexpressing mice indicated that IL-18 is anorexigenic and can modulate feeding, but also energy homeostasis, influencing obesity and insulin resistance $[10,11]$. The mechanisms through which IL-18 exerts these effects are largely unknown but central action was proposed following the observation that i.c.v. injections of exogenous IL-18 induces sleep [72] and anorexia [11]. The recent demonstration that IL-18 functional and regulatory subunits of the IL-18R are expressed in several brain regions including the hippocampus, the hypothalamus and the cortex provided a molecular and cellular basis for the central action of IL-18 in modulating these functions [26].

Evidence for the role of IL-18 as modulator of neuronal functions includes studies on the hippocampal system, a structure that plays a major role in memory and in cognition. For instance, IL-18 reduces long term potentiation (LTP) in the rat dentate gyrus, possibly through the involvement of metabotropic glutamate receptors $[48,49,74,75]$. In particular, IL-18 had no effect on baseline synaptic transmission or paired pulse depression, but significantly depressed the amplitude of NMDA receptor-mediated field excitatory post synaptic potentials [75] providing evidence of a direct neuromodulatory role for IL-18 in synaptic plasticity. It is possible that IL-18 may act directly on the neurons of the dentate gyrus, moreover, its action may be regulated by the relative level of IL-18R $\alpha$ type I and type II, both highly expressed in these cells [26]. Work on CA1 pyramidal neurons of mouse hippocampal slices demonstrated that IL-18 stimulated synaptically released glutamate and enhanced postsynaptic AMPA receptor responses, thereby facilitating basal hippocampal synaptic transmission without affecting LTP [76].

Recently an ex vivo study found that LPS-induced IL18 elevation in the brain was unable to affect LTP in the CA1 hippocampal subregion [77]. However, when comparing wild-type and IL-18 KO mice, the same study demonstrated that IL-18 regulates fear memory and spatial learning. In particular, assessment of spatial learning and memory with the water maze test showed that compared to wild-type mice IL-18 KO mice exhibit prolonged acquisition latency and that this phenotype was rescued by i.c.v. injection of IL-18. 


\section{Stress and the hypothalamic-pituitary-adrenal axis}

IL-18 occupies a peculiar role in stress response both centrally and peripherally. This subject was recently extensively reviewed and we briefly refer to it here only for those aspects relevant to understanding of the central actions of this cytokine [78].

In response to restraint stress, IL-18 null mice showed a markedly reduced morphological microglial activation in the thalamus, hypothalamus, hippocampus, substantia nigra and central gray area [62]. In addition, IL-18 expression was elevated by restraint stress in the neurons of the medial habenula [56]. Since the habenula is a potential site for the interaction of neuro-endocrine and immune functions, the possibility exists that IL-18 might mediate the communication between the CNS and the periphery. Indeed, there is a general agreement that IL-18 may regulate hypothalamic-pituitary axis activity, possibly mediating the stress response of the adrenal gland [20,78,79]. In this respect, stress has been shown to induce transient IL-18 mRNA elevation in rat pituitary cells where increase of the IL-18 mRNA level was observed also after adrenalectomy [57].

IL-18 is also produced in the neurohypophysis [20] as well as in the adenohypophysis where in situ hybridization combined with immunohistochemistry demonstrated its expression in corticotrope cells [57]. In addition, bovine somatotropes have been shown to produce IL-18 and IL-18R $\alpha$ was co-localized with IL-18, or growth hormone, suggesting the possibility that IL-18 acts on somatotropes through the autocrine pathway [80]. However, IL-18 seems to also act at the hypothalamic level. Indeed, the application of IL-18 in rat hypothalamic explants decreases basal and $\mathrm{KCl}$-stimulated corticotropin-releasing hormones $(\mathrm{CRH})$, as well as $\mathrm{CRH}$ gene expression [81]. In particular, the cytokine did not modify basal PGE2 production but abolished production stimulated by IL- $1 \beta$ demonstrating that IL18 possesses a profile of in vitro neuroendocrine activities opposed to, and even antagonizing, those of IL-1 $\beta$. Recently, IL-18 was localized in the marginal cell layer of the bovine and porcine Rathke's pouch, that is assumed to embody a stem/progenitor cell compartment of the postnatal pituitary gland $[54,55]$. Interestingly, stimulation of a cloned anterior pituitary-derived cell line (from the bovine anterior pituitary gland) with IL-18 increased expression of mRNAs of a different cytokine suggesting the possibility that IL-18 may modulate not only the immuno-endocrine function of the pituitary cells but also their development [55].

\section{Microglia and neuroinflammation}

Functional maturation and activation of IL-18 can occur in the brain under inflammatory conditions. Indeed, as extensively reviewed by Felderhoff-Mueser and colleagues [82], experimental and clinical studies suggest that binding of IL-18 occurs in several neuroinflammatory associated pathological conditions including microbial infections, focal cerebral ischemia, Wallerian degeneration and hypoxic-ischemic, hyperoxic and traumatic brain injuries (e.g., stroke). Further evidence comes from recent papers reporting an activation of IL-18 in the brain of mice that underwent thromboembolic stroke [83] or an increase of IL-18 levels after hypoxia-ischemia in the juvenile hippocampus of mice [84].

During CNS inflammation, the IL-18 system may have an important role in the activation and response of microglia and possibly infiltrating cells. As mentioned above, microglia cells can synthesize and respond to IL18 [20,59-61]. IL-18 KO mice had impaired microglia activation with reduced expression of $\mathrm{Ca}^{2+-}$ binding protein regulating phagocytic functions that resulted in reduced clearance of neurovirulent influenza A virus [85]. In the absence of infection IL-18 deficient mice also showed diminished stress-induced morphological microglial hypertrophy [62].

Interestingly, IL-1 $\beta$ is upregulated within $4 \mathrm{~h}$ of focal ischemia in rat brain, but IL-18 is upregulated much later, at time points associated with infiltration of peripheral immune cells, thus suggesting different roles for these interleukins in the regulation of glial functions [86]. In this respect, it was shown that mice infected with Japanese Encephalitis produce IL-18 and IL-1 $\beta$ from microglia and astroglia [59]. Both interleukins are capable of inducing pro-inflammatory cytokines and chemokines from human microglia and astroglia, although IL-18 seems to be more potent than IL-1 $\beta$.

In the spinal cord, IL-18 seems to play a role in the innate inflammatory response. Indeed, moderate cervical contusive spinal cord injury induced processing of IL-18 in neurons of the rat spinal cord [87]. In addition, nerve injury induced a striking increase in IL-18 and IL-18R expression in the dorsal horn, and IL-18 and IL-18R were upregulated in hyperactive microglia and astrocytes, respectively $[47,88]$. Intrathecal injection of IL-18 induced behavioral, morphological, and biochemical changes similar to those observed after nerve injury [47], suggesting that IL-18-mediated microglia/astrocyte interactions in the spinal cord have a substantial role in the generation of tactile allodynia.

\section{Autoimmune neurodegenerative disease}

A pivotal role for IL-18, in the pathogenesis of autoimmune neurodegenerative disease has been proposed. High levels of IL-18 mRNA were found in the brain and the spinal cord of rats with experimental autoimmune encephalomyelitis (EAE), an animal model of multiple sclerosis (MS) [89,90]. Elevated IL-18 transcript was found at the onset and throughout the course of the disease. A different study showed that IL-18 increases severity of EAE [91]. Moreover, it has been 
demonstrated that anti-IL-18 antibodies or targeted overexpression of IL-18BP in the CNS had preventive effects on the induction of EAE[90,92]. These observations suggested a role for IL-18 in MS, IL-18 KO mice were susceptible to EAE, whereas IL- $18 \mathrm{R} \alpha \mathrm{KO}$ mice or IL-18 KO mice treated with anti-IL-18R $\alpha$ antibodies were not [93]. Thus, alternative IL-18R $\alpha$ ligands with encephalitogenic properties may exist [93]. In EAE-susceptible Dark Agouti rats, the basal and post-immunization (day 5, 7 and 12) levels of IL-18R $\alpha$ in lymph node cells were significantly higher than in the EAE-resistant Piebald Virol Glaxo rats [94].

In human, serum and cerebrospinal fluid levels of IL18 are elevated in patients with MS [95-98] and IL-18 positive cells have been detected in demyelinating brain lesions from MS patients [99].

The pathological role of IL-18 in EAE is also supported by the up-regulation of caspase-1 (required to convert IL-18 precursor protein into its biologically active mature form) mRNA in the spinal cord of rats with EAE [89], and decreased disease severity in caspase-1 KO mice [100]. Finally, peripheral blood mononuclear cells from patients with MS have elevated caspase-1 mRNA levels [95,101].

In addition to a role in MS there is also evidence to support a function for IL-18 in the onset and progression of autoimmune CNS disease. For instance, infection of microglia lines with Theiler's murine encephalomyelitis virus (which causes the development of a chronicprogressive autoimmune demyelinating disease) significantly upregulates the expression of cytokines involved in innate immunity, including IL-18 [102].

\section{Neurodegenerative disorders}

Alzheimer's Disease (AD) is the most common type of human dementia. It is characterized clinically by a gradual but progressive decline in memory and pathologically by neuritic plaques, neuro-fibrillary tangles, and the loss of synapses and neurons [103]. Inflammatory processes were proposed to contribute to neurodegeneration in $\mathrm{AD}$ and extensive studies indicated that IL-1 is a pivotal cytokine in mediating direct neuronal loss and sustaining microglia activation leading to further cellular damage in AD [104]. Microglia-derived inflammatory cytokines can initiate nerve cell degeneration and enhance the plaque production typically found in $\mathrm{AD}$ [105]. Increasing evidence indicates that IL-18 may have a role in this scenario.

For instance, the levels of IL-18 transcript and protein were increased in the frontal lobe of AD patients compared to healthy age-matched controls. In these brains IL-18 was found in microglia, astrocytes and in neurons that co-localize with amyloid- $\beta$-plaques and with tau [106], suggesting that amyloid- $\beta$ may induce the synthesis of IL-18, and IL-18 kinases involved in tau phosphorylation as a part of the amyloid-associated inflammatory reaction. Additionally, IL-18 can enhance protein levels of Cdk5/p35 and GSK-3 $\beta$ kinases, tau phosphorylation and cell cycle activators in neuronlike differentiated human SH-SY5Y neuroblastoma cells [50]. Thus, on a pathway leading to AD, IL-18 may have an impact on the hyperphosphorylation of tau but also on cell cycle related mechanisms. In the plasma, the levels of IL-18 were significantly elevated in patients with $\mathrm{AD}$, vascular dementia, and mild cognitive impairment compared to the control group $[107,108]$. Interestingly, IL-18 levels were higher in $\mathrm{AD}$-mild patients, were slightly lower in $\mathrm{AD}$-moderate patients, whereas no significant difference was observed between AD-severe patients and non-demented age-matched subjects [109], suggesting a gradual decline of immune responsiveness in AD. Although other studies showed no differences in circulating IL18 levels measured between AD patients (both mild cognitive impairment and severe $\mathrm{AD}$ patients) and controls $[106,110,111]$, a significant increased production of IL-18 was obtained from stimulated blood mononuclear cells or macrophages of peripheral blood of AD patients $[111,112]$. Furthermore, a significant correlation between IL-18 peripheral production and cognitive decline was observed in $\mathrm{AD}$ patients. Overall, these data indicate that IL-18-related inflammatory pathways, are exacerbated in the peripheral blood of $\mathrm{AD}$ patients, and that this cytokine may indeed participate in pathogenic processes leading to dementia.

Genetic association studies reported that two functional polymorphisms (137G/C and -607C/A) in IL-18 promoter may increase the risk of developing sporadic late onset $\mathrm{AD}$ in the Han Chinese population [113]. An association between 137G/C and -607C/A polymorphisms and the susceptibility/clinical outcome of $\mathrm{AD}$ was also suggested in an Italian population [114], although these correlations remain controversial. Indeed, in another Italian population a lack of association between IL-18 gene promoter polymorphisms and onset of AD was reported, indicating that the association of IL-18 promoter polymorphisms with $\mathrm{AD}$ is not so strong, $\mathrm{AD}$ being a multifactorial disease [115]. Importantly, IL-18 promoter remains poorly characterized.

Finally, it has been hypothesized that increased production of IL-18 in the brain may lead to motor and cognitive dysfunctions, leading to the development of HIV-associated dementia. Thus, IL-18 concentrations in HIV-infected persons are likely to play an important role in the development and progression of the infection toward AIDS and associated clinical conditions [116].

In Parkinsonism, there is evidence of chronic inflammation in the substantia nigra and striatum. Activated microglia, producing proinflammatory cytokines, 
surround the degenerating dopaminergic neurons and may contribute to dopaminergic neuron loss. In an experimental model of Parkinson's disease that utilized injection of the dopaminergic specific neurotoxin MPTP the number of activated microglial cells in the substantia nigra pars compacta of IL-18 $\mathrm{KO}$ mice was reduced compared to wild-type [117], indicating the possibility that IL-18 may participate in microglial activation and dopaminergic neurodegeneration.

\section{Neuropsychiatric disorders}

Several groups found that depressed and schizophrenic patients have high circulating levels of pro-inflammatory cytokines [118-123]. Others reported that psychotic episodes often occur in conditions characterized by elevated levels of pro-inflammatory cytokines, for instance during inflammation or in patients suffering from immune diseases [124-127].

Other studies suggested that the correlation between inflammatory markers and psychiatric disorders may be more that merely associative, with inflammation actually contributing to mental disorders. Improvement in psychiatric symptoms has been recently reported in patients treated with anti-inflammatory drugs for other indications [128] and functional allelic variants of genes codifying for pro-inflammatory cytokines were associated with reduced responsiveness to antidepressant therapy $[129,130]$. It was also recently demonstrated that IL-6 plays a pivotal role in the pharmacological ketamine model of schizophrenia by modulating the NADPH-oxidase increase of superoxide affecting parvalbumin interneurons [131]. An interesting line of research is exploring the possibility that these actions may be developmental, with cytokines influencing early-life programming of brain functions [132].

At present evidence linking IL-18 and psychiatric disorders are primarily associative. IL-18 mRNA expression is elevated in subordinate rat models with depression with respect to dominant rats [133]. A significant elevation of circulating plasma levels of IL-18 has been reported in subjects affected by schizophrenia and were normalized by pharmacological treatment with risperidone, a dopamine antagonist with antipsychotic activity $[134,135]$. Normalization was demonstrated also within 6 month of treatment with the antipsychotic clozepine [134] although the possibility that these effects could be due to clozepine's effects on leukocyte numbers cannot be excluded. The serum levels of IL-18 were also significantly higher in moderate-severe depression patients, further suggesting that the pathophysiology of depression is associated with an inflammatory response involving IL-18 [136,137]. Coincidentally, IL-18 is also elevated after stroke, a condition followed by emotional disorders [138-140].
The significance of these correlations with respect to the role of the IL-18 system to neurophsychiatric disease pathophysiology or manifestation remains to be determined. Caution should be taken particularly since peripheral IL-18 can be subject to neurogenic stimulation or stress $[20,78,141-143]$. It is thus difficult to determine whether IL-18 elevation contributes to these pathologies or whether it is a consequence of the disorders. Indeed, Kokai and colleagues suggest that IL-18 can be considered a psychologic stress-associated marker since they demonstrated that exposure to stressful events (i.e., panic attack in human, restraint stress in mice), the most important precipitating factor in depression, induces a prompt increase in the level of circulating IL18 [136].

Regardless, elevated IL-18 levels have the potential to contribute to several of the symptoms associated with neuropsychiatric disorders. For instance, like other pro-inflammatory cytokines, IL-18 may participate in the control of the activity of the HPA axis reported to be dysregulated in depression [78,144-146]. IL-18 may antagonize glucocorticoid signalling via activation of NF- $\kappa \mathrm{B}$ and $\mathrm{p} 38$ MAPK possibly disrupting glucocorticoid-dependent negative feedback on the HPA axis [147-149]. Finally, IL-18 can affect other hallmarks of depression impairing learning and memory by acting as an attenuator of long-term potentiation, and inducing lethargy and loss of appetite $[11,72,74]$.

\section{Other central actions of IL-18}

Three groups investigated the action of IL-18 in rodents following administration of $\mathrm{KA}$, an agonist of the kainate receptors inducing seizure, cerebellar ataxia and exitotoxic mediated neuronal loss $[53,60,150]$. In mouse hippocampus KA elevated IL-18 and IL-18R expression on microglial cells progressively 3 days after treatment [60]. The authors hypothesized that similar to what was observed peripherally in studies of the immune system, IL-18 may contribute to cellular damage. This hypothesis was partially supported by another group showing that the KA-induced hippocampal neurodegeneration was shown to be more severe in IL-18 KO mice compared to wild-type littermates [150]. Yet, in recombinant mice with the same pre-treatment, IL-18 aggravated both the clinical and pathological signs of neurodegeneration in a dosedependent manner.

In the cerebellum, where KA was demonstrate to induce ataxia partially via elevation of IL- $1 \beta$, exogenous IL-18 was protective and played a positive role in the recovery from kainate-induced ataxia [53]. Consistently, IL-18 KO and IL-18R $\alpha$ KO mice show delay in recovery from kainate-induced ataxia. The antagonizing effects of IL- 18 and IL- $1 \beta$ also observed in the peripheral effects of IL-1 $\beta$ on fever, [73] are intriguing 
particularly since these cytokines share many similarities including their signalling. Preliminary observations suggest that these effects may be explained by IL- $1 \beta$ and IL-18 targeting different cells or activating distinct signalling [53].

Some groups have investigated the possibility that IL-18 could be used against glioma, a common and highly aggressive type of brain tumor with poor longterm prognosis [151]. In this respect, IL-18 was investigated alone or in synergism with IL-12 or Fas, for its ability to induce INF $\gamma$ and NO inducing a cytotoxic response against glioma cells [152]. Systemic or intracerebral administration of IL-18 inhibited the growth of inoculated glioma cells and prolonged the survival of mice with subcutaneous or brain tumors, respectively [153]. Antitumor activity against glioma was also found in mice treated with IL-18 and IL-12 via Semliki Forest virus $[154,155]$ or with a combination of IL-18 and Fas [156]. Finally, encouraging data were also reported by overexpressing IL-18 in mesenchymal cells of rats [157].

\section{Conclusions}

Investigation on the presence of IL-18 in the CNS began soon after its discovery as a co-stimulator of INF- $\gamma$ production in the immune system $[1,20,158,159]$. Initially IL-18 was investigated for its similarities with IL- $1 \beta$ as a possible mediator of sickness behavior and of local inflammatory reactions associated with neuronal damage. These actions were both demonstrated and IL18 was shown to promote loss of appetite, sleep and inhibition of LTP, as well as to be produced by and active in microglial cells, and to possibly contribute to neurodegenerative diseases.

Yet, two observations suggest that IL-18 has a central role and function that may be unique and distinct from those of IL- $1 \beta$ or other cytokines. The first being the recognition that Il-18 and Il- $1 \beta$, when their combined action was tested, may have antagonizing effects such as those occurring in fever and in kainate-induced cerebellar ataxia. The second was the finding that IL-18R is constitutively and broadly expressed in neuronal cells throughout the rodent brain. This finding opened the possibility of a direct action of IL-18 on neuronal functions particularly in all of the CNS disorders showed to be correlated to elevated cytokine levels.

Thus, the investigation of the central action of IL-18 may be considered in its infancy and the significance of the neuronal IL-18R complex and of its isoforms remains to be determined. Among the intriguing peculiarities of the central role of IL-18 is that despite the constitutive expression of the receptor, the regulation of IL-18 action appears to be regulated by the existence of truncated isoforms and by the fact that under normal physiological conditions IL-18 is not easily found in the CNS. Interestingly, the genes encoding for IL-18 and its receptors are subject to differential promoter usage and their transcription to differential splicing indicating that these molecules have the potential of being produced in a tissue/cell specific way in response to different stimuli $[26,78]$. It will be important to determine which physiological or pathological conditions modulate these molecules.

Also unexplored is the investigation of the possible role of IL-18 in CNS development suggested by work on microglial cultures from newborn mice and brain homogenates where IL-18 was preferentially expressed during early postnatal stages and subsequently downregulated, being virtually absent in the brains of adult mice [61]. Additionally, the activated microglia-derived cytokines, including IL-18, may either inhibit the neuronal differentiation or induce neuronal cell death in the rat neural progenitor cell culture, which are cells capable of giving rise to various neuronal and glial cell populations in the developing and adult CNS [160]. Finally, in adult rodents IL-18 is produced in ependymal cells [56] considered a primary source of neural stem cells in response to injury [161]. The possible role of IL-18 in their differentiation has also not been investigated.

Work on existing IL-18 and IL-18R null mice as well as the development of new experimental models including CNS specific null or overexpressor mice and the identification of suitable in vitro systems will determine the specificity of the central effects of IL-18 in health and disease.

\section{Acknowledgements}

Supported by The Ellison Medical Foundation and NIH HL088083 and grantin-aid for Science Research from the Ministry of Education, Culture, Sports, Science, and Technology, Japan (20500359).

\section{Author details}

'Department of Biomedical Sciences, University of Modena and Reggio Emilia, Italy. ${ }^{2}$ Department of Environmental Sciences, University of Tuscia, Viterbo, Italy. ${ }^{3}$ Department of Physiology, Nippon Medical School, 1-1-5 Sendagi Bunkyo-ku, Tokyo 113-8602, Japan. ${ }^{4}$ Molecular and Integrative Neurosciences Department, The Scripps Research Institute, CA, USA.

\section{Authors' contributions}

SA and DC wrote the initial draft of the manuscript, SS and BC contributed to its final version. All authors read and approved the final manuscript.

\section{Competing interests}

The authors declare that they have no competing interests.

Received: 10 December 2009

Accepted: 29 January 2010 Published: 29 January 2010

\section{References}

1. Okamura H, Tsutsi H, Komatsu T, Yutsudo M, Hakura A, Tanimoto T, Torigoe K, Okura T, Nukada Y, Hattori $K$, et al: Cloning of a new cytokine that induces IFN-gamma production by T cells. Nature 1995, 378:88-91. 
2. Dinarello CA: IL-18: A TH1-inducing, proinflammatory cytokine and new member of the IL-1 family. J Allergy Clin Immunol 1999, 103:11-24.

3. Nakanishi K, Yoshimoto T, Tsutsui H, Okamura H: Interleukin-18 is a unique cytokine that stimulates both Th1 and Th2 responses depending on its cytokine milieu. Cytokine Growth Factor Rev 2001, 12:53-72.

4. Arend WP, Palmer G, Gabay C: IL-1, IL-18, and IL-33 families of cytokines. Immunol Rev 2008, 223:20-38.

5. Boraschi D, Dinarello CA: IL-18 in autoimmunity: review. Eur Cytokine Netw 2006, 17:224-252.

6. Park $\mathrm{S}$, Cheon $\mathrm{S}$, Cho D: The dual effects of interleukin-18 in tumor progression. Cell Mol Immunol 2007, 4:329-335.

7. Dinarello CA: Interleukin-18 and the pathogenesis of inflammatory diseases. Semin Nephrol 2007, 27:98-114.

8. Dinarello CA, Fantuzzi G: Interleukin-18 and host defense against infection. J Infect Dis 2003, 187(Suppl 2):S370-384.

9. Kawakami K: Interleukin-18 and host defense against infectious pathogens. J Immunother 2002, 25(Suppl 1):S12-19.

10. Netea MG, Joosten LA, Lewis E, Jensen DR, Voshol PJ, Kullberg BJ, Tack CJ, van Krieken H, Kim SH, Stalenhoef AF, Loo van de FA, Verschueren I, Pulawa L, Akira S, Eckel RH, Dinarello CA, Berg van den W, Meer van der JW: Deficiency of interleukin-18 in mice leads to hyperphagia, obesity and insulin resistance. Nat Med 2006, 12:650-656.

11. Zorrilla EP, Sanchez-Alavez M, Sugama S, Brennan M, Fernandez R, Bartfai T, Conti B: Interleukin-18 controls energy homeostasis by suppressing appetite and feed efficiency. Proc Natl Acad Sci USA 2007. 104:11097-11102.

12. Akita K, Ohtsuki T, Nukada Y, Tanimoto T, Namba M, Okura T, TakakuraYamamoto R, Torigoe K, Gu Y, Su MS, Fujii M, Satoh-Itoh M, Yamamoto K, Kohno K, Ikeda M, Kurimoto M: Involvement of caspase-1 and caspase-3 in the production and processing of mature human interleukin 18 in monocytic THP.1 cells. J Biol Chem 1997, 272:26595-26603.

13. Fantuzzi G, Puren AJ, Harding MW, Livingston DJ, Dinarello CA: Interleukin18 regulation of interferon gamma production and cell proliferation as shown in interleukin-1 beta-converting enzyme (caspase-1)-deficient mice. Blood 1998, 91:2118-2125.

14. Ghayur T, Banerjee S, Hugunin M, Butler D, Herzog L, Carter A, Quintal L, Sekut L, Talanian R, Paskind M, Wong W, Kamen R, Tracey D, Allen H: Caspase-1 processes IFN-gamma-inducing factor and regulates LPSinduced IFN-gamma production. Nature 1997, 386:619-623.

15. Gu Y, Kuida K, Tsutsui H, Ku G, Hsiao K, Fleming MA, Hayashi N, Higashino K, Okamura $\mathrm{H}$, Nakanishi K, et al: Activation of interferongamma inducing factor mediated by interleukin-1beta converting enzyme. Science 1997, 275:206-209.

16. Ushio S, Namba M, Okura T, Hattori K, Nukada Y, Akita K, Tanabe F, Konishi K, Micallef M, Fujii M, et al: Cloning of the cDNA for human IFNgamma-inducing factor, expression in Escherichia coli, and studies on the biologic activities of the protein. I Immunol 1996, 156:4274-4279.

17. Fantuzzi G, Dinarello CA: Interleukin-18 and interleukin-1 beta: two cytokine substrates for ICE (caspase-1). J Clin Immunol 1999, 19:1-11

18. Gracie JA: Interleukin-18 as a potential target in inflammatory arthritis. Clin Exp Immunol 2004, 136:402-404.

19. Sugawara $S$, Uehara A, Nochi $T$, Yamaguchi $T$, Ueda H, Sugiyama A, Hanzawa K, Kumagai K, Okamura H, Takada H: Neutrophil proteinase 3mediated induction of bioactive IL-18 secretion by human oral epithelial cells. J Immunol 2001, 167:6568-6575.

20. Conti B, Jahng JW, Tinti C, Son JH, Joh TH: Induction of interferon-gamma inducing factor in the adrenal cortex. J Biol Chem 1997, 272:2035-2037.

21. Yang YJ, Wang ZY, Chen SH, Ge XR: Cloning and characterization of a new isoform of mouse interleukin-18. Acta Biochim Biophys $\operatorname{Sin}$ (Shanghai) 2005, 37:826-834.

22. O'Neill LA, Dinarello CA: The IL-1 receptor/toll-like receptor superfamily: crucial receptors for inflammation and host defense. Immunol Today 2000, 21:206-209.

23. Sims JE: IL-1 and IL-18 receptors, and their extended family. Curr Opin Immunol 2002, 14:117-122.

24. Sergi B, Penttila I: Interleukin 18 receptor. J Biol Regul Homeost Agents 2004, 18:55-61.

25. Thomassen E, Bird TA, Renshaw BR, Kennedy MK, Sims JE: Binding of interleukin-18 to the interleukin-1 receptor homologous receptor IL1 Rrp1 leads to activation of signaling pathways similar to those used by interleukin-1. J Interferon Cytokine Res 1998, 18:1077-1088.
26. Alboni S, Cervia D, Ross B, Montanari C, Gonzalez AS, Sanchez-Alavez M, Marcondes MC, De Vries D, Sugama S, Brunello N, et al: Mapping of the full length and the truncated interleukin-18 receptor alpha in the mouse brain. J Neuroimmunol 2009, 214:43-54.

27. Colotta F, Dower SK, Sims JE, Mantovani A: The type II 'decoy' receptor: a novel regulatory pathway for interleukin 1. Immunol Today 1994, 15:562-566.

28. Andre R, Wheeler RD, Collins PD, Luheshi GN, Pickering-Brown S, Kimber I, Rothwell NJ, Pinteaux E: Identification of a truncated IL-18R beta mRNA: a putative regulator of IL-18 expressed in rat brain. J Neuroimmunol 2003, 145:40-45.

29. Fiszer D, Rozwadowska N, Rychlewski L, Kosicki W, Kurpisz M: Identification of IL-18RAP mRNA truncated splice variants in human testis and the other human tissues. Cytokine 2007, 39:178-183.

30. Im SH, Kim SH, Azam T, Venkatesh N, Dinarello CA, Fuchs S, Souroujon MC: Rat interleukin-18 binding protein: cloning, expression, and characterization. J Interferon Cytokine Res 2002, 22:321-328.

31. Kim SH, Azam T, Novick D, Yoon DY, Reznikov LL, Bufler P, Rubinstein M, Dinarello CA: Identification of amino acid residues critical for biological activity in human interleukin-18. J Biol Chem 2002, 277:10998-11003.

32. Novick D, Kim SH, Fantuzzi G, Reznikov LL, Dinarello CA, Rubinstein M: Interleukin-18 binding protein: a novel modulator of the Th1 cytokine response. Immunity 1999, 10:127-136.

33. Kim SH, Eisenstein M, Reznikov L, Fantuzzi G, Novick D, Rubinstein M, Dinarello CA: Structural requirements of six naturally occurring isoforms of the IL-18 binding protein to inhibit IL-18. Proc Natl Acad Sci USA 2000, 97:1190-1195.

34. Bufler P, Azam T, Gamboni-Robertson F, Reznikov LL, Kumar S, Dinarello CA, Kim SH: A complex of the IL-1 homologue IL-1F7b and IL-18-binding protein reduces IL-18 activity. Proc Natl Acad Sci USA 2002, 99:13723-13728.

35. Busfield SJ, Comrack CA, Yu G, Chickering TW, Smutko JS, Zhou H, Leiby KR, Holmgren LM, Gearing DP, Pan Y: Identification and gene organization of three novel members of the IL-1 family on human chromosome 2 . Genomics 2000, 66:213-216

36. Kumar S, McDonnell PC, Lehr R, Tierney L, Tzimas MN, Griswold DE, Capper EA, Tal-Singer R, Wells Gl, Doyle ML, Young PR: Identification and initial characterization of four novel members of the interleukin-1 family. J Biol Chem 2000, 275:10308-10314

37. Pan G, Risser P, Mao W, Baldwin DT, Zhong AW, Filvaroff E, Yansura D, Lewis L, Eigenbrot C, Henzel WJ, Vandlen R: IL-1H, an interleukin 1-related protein that binds IL-18 receptor/IL-1Rrp. Cytokine 2001, 13:1-7.

38. Smith DE, Renshaw BR, Ketchem RR, Kubin M, Garka KE, Sims JE: Four new members expand the interleukin-1 superfamily. J Biol Chem 2000, 275:1169-1175.

39. Taylor SL, Renshaw BR, Garka KE, Smith DE, Sims JE: Genomic organization of the interleukin-1 locus. Genomics 2002, 79:726-733.

40. Kumar S, Hanning CR, Brigham-Burke MR, Rieman DJ, Lehr R, Khandekar S, Kirkpatrick RB, Scott GF, Lee JC, Lynch FJ, et al: Interleukin-1F7B (IL-1H4/IL1F7) is processed by caspase- 1 and mature IL-1F7B binds to the IL-18 receptor but does not induce IFN-gamma production. Cytokine 2002, 18:61-71.

41. Dinarello CA: Interleukin-18, a proinflammatory cytokine. Eur Cytokine Netw 2000, 11:483-486.

42. Gracie JA, Robertson SE, McInnes IB: Interleukin-18. J Leukoc Biol 2003, 73:213-224.

43. Shimoda K, Tsutsui H, Aoki K, Kato K, Matsuda T, Numata A, Takase K, Yamamoto T, Nukina $H$, Hoshino T, et al: Partial impairment of interleukin12 (IL-12) and IL-18 signaling in Tyk2-deficient mice. Blood 2002, 99:2094-2099.

44. Kalina U, Kauschat D, Koyama N, Nuernberger H, Ballas K, Koschmieder S, Bug G, Hofmann WK, Hoelzer D, Ottmann OG: IL-18 activates STAT3 in the natural killer cell line 92, augments cytotoxic activity, and mediates IFNgamma production by the stress kinase $\mathrm{p} 38$ and by the extracellular regulated kinases p44erk-1 and p42erk-21. J Immunol 2000, 165:1307-1313.

45. Chandrasekar B, Patel DN, Mummidi S, Kim JW, Clark RA, Valente AJ: Interleukin-18 suppresses adiponectin expression in 3T3-L1 adipocytes via a novel signal transduction pathway involving ERK1/2-dependent NFATc4 phosphorylation. J Biol Chem 2008, 283:4200-4209. 
46. Fortin CF, Ear T, McDonald PP: Autocrine role of endogenous interleukin18 on inflammatory cytokine generation by human neutrophils. Faseb $J$ 2009, 23:194-203.

47. Miyoshi K, Obata K, Kondo T, Okamura H, Noguchi K: Interleukin-18mediated microglia/astrocyte interaction in the spinal cord enhances neuropathic pain processing after nerve injury. $J$ Neurosci 2008, 28:12775-12787.

48. Cumiskey D, Pickering M, O'Connor JJ: Interleukin-18 mediated inhibition of LTP in the rat dentate gyrus is attenuated in the presence of mGluR antagonists. Neurosci Lett 2007, 412:206-210.

49. Curran BP, Murray HJ, O'Connor JJ: A role for c-Jun N-terminal kinase in the inhibition of long-term potentiation by interleukin-1 beta and longterm depression in the rat dentate gyrus in vitro. Neuroscience 2003, 118:347-357.

50. Ojala JO, Sutinen EM, Salminen A, Pirttila T: Interleukin-18 increases expression of kinases involved in tau phosphorylation in SH-SY5Y neuroblastoma cells. J Neuroimmunol 2008, 205:86-93.

51. Culhane AC, Hall MD, Rothwell NJ, Luheshi GN: Cloning of rat brain interleukin-18 cDNA. Mol Psychiatry 1998, 3:362-366.

52. Wheeler RD, Culhane AC, Hall MD, Pickering-Brown S, Rothwell NJ, Luheshi GN: Detection of the interleukin 18 family in rat brain by RTPCR. Brain Res Mol Brain Res 2000, 77:290-293.

53. Andoh T, Kishi H, Motoki K, Nakanishi K, Kuraishi Y, Muraguchi A: Protective effect of IL-18 on kainate- and IL-1 beta-induced cerebellar ataxia in mice. J Immunol 2008, 180:2322-2328.

54. Nagai Y, Ogasawara $H$, Taketa Y, Aso H, Kanaya T, Miyake M, Watanabe $K$, Ohwada S, Muneta Y, Yamaguchi T: Expression of inflammatory-related factors in porcine anterior pituitary-derived cell line. Vet Immunol Immunopathol 2008, 124:201-208.

55. Nagai Y, Ogasawara H, Taketa Y, Aso H, Tanaka S, Kanaya T, Watanabe K, Ohwada S, Muneta Y, Yamaguchi T: Bovine anterior pituitary progenitor cell line expresses interleukin (IL)-18 and IL-18 receptor. J Neuroendocrinol 2008, 20:1233-1241.

56. Sugama S, Cho BP, Baker H, Joh TH, Lucero J, Conti B: Neurons of the superior nucleus of the medial habenula and ependymal cells express IL-18 in rat CNS. Brain Res 2002, 958:1-9.

57. Wang N, Sugama S, Conti B, Teramoto A, Shibasaki T: Interleukin-18 mRNA expression in the rat pituitary gland. J Neuroimmunol 2006, 173:117-125.

58. Conti B, Park LC, Calingasan NY, Kim Y, Kim H, Bae Y, Gibson GE, Joh TH: Cultures of astrocytes and microglia express interleukin 18. Brain Res $\mathrm{Mol}$ Brain Res 1999, 67:46-52

59. Das S, Mishra MK, Ghosh J, Basu A: Japanese Encephalitis Virus infection induces IL-18 and IL-1beta in microglia and astrocytes: correlation with in vitro cytokine responsiveness of glial cells and subsequent neuronal death. J Neuroimmunol 2008, 195:60-72.

60. Jeon GS, Park SK, Park SW, Kim DW, Chung CK, Cho SS: Glial expression of interleukin-18 and its receptor after excitotoxic damage in the mouse hippocampus. Neurochem Res 2008, 33:179-184.

61. Prinz $M$, Hanisch UK: Murine microglial cells produce and respond to interleukin-18. J Neurochem 1999, 72:2215-2218.

62. Sugama S, Fujita M, Hashimoto M, Conti B: Stress induced morphological microglial activation in the rodent brain: involvement of interleukin-18. Neuroscience 2007, 146:1388-1399.

63. Suk K, Yeou Kim S, Kim H: Regulation of IL-18 production by IFN gamma and PGE2 in mouse microglial cells: involvement of NF-kB pathway in the regulatory processes. Immunol Lett 2001, 77:79-85.

64. Parnet P, Garka KE, Bonnert TP, Dower SK, Sims JE: IL-1Rrp is a novel receptor-like molecule similar to the type I interleukin-1 receptor and its homologues T1/ST2 and IL-1R ACP. J Biol Chem 1996, 271:3967-3970.

65. Born TL, Thomassen E, Bird TA, Sims JE: Cloning of a novel receptor subunit, AcPL, required for interleukin-18 signaling. J Biol Chem 1998, 273:29445-29450.

66. Otsuki M, Kusumoto K, Murakami Y, Kanayama M, Takeuchi S, Takahashi S: Expression of interleukin-18 receptor mRNA in the mouse endometrium. J Reprod Dev 2007, 53:59-68.

67. Hedtjarn M, Leverin AL, Eriksson K, Blomgren K, Mallard C, Hagberg H: Interleukin-18 involvement in hypoxic-ischemic brain injury. J Neurosci 2002, 22:5910-5919.

68. Wheeler RD, Brough D, Le Feuvre RA, Takeda K, Iwakura Y, Luheshi GN, Rothwell NJ: Interleukin-18 induces expression and release of cytokines from murine glial cells: interactions with interleukin-1 beta. J Neurochem 2003, 85:1412-1420.

69. Dantzer R, Bluthe RM, Gheusi G, Cremona S, Laye S, Parnet P, Kelley KW: Molecular basis of sickness behavior. Ann N Y Acad Sci 1998, 856:132-138.

70. Dantzer R, Kelley KW: Twenty years of research on cytokine-induced sickness behavior. Brain Behav Immun 2007, 21:153-160.

71. Dantzer R, O'Connor JC, Freund GG, Johnson RW, Kelley KW: From inflammation to sickness and depression: when the immune system subjugates the brain. Nat Rev Neurosci 2008, 9:46-56.

72. Kubota T, Fang J, Brown RA, Krueger JM: Interleukin-18 promotes sleep in rabbits and rats. Am J Physiol Regul Integr Comp Physiol 2001, 281: R828-838.

73. Gatti S, Beck J, Fantuzzi G, Bartfai T, Dinarello CA: Effect of interleukin-18 on mouse core body temperature. Am J Physiol Regul Integr Comp Physiol 2002, 282:R702-709.

74. Cumiskey D, Curran BP, Herron CE, O'Connor JJ: A role for inflammatory mediators in the IL-18 mediated attenuation of LTP in the rat dentate gyrus. Neuropharmacology 2007, 52:1616-1623.

75. Curran B, O'Connor JJ: The pro-inflammatory cytokine interleukin-18 impairs long-term potentiation and NMDA receptor-mediated transmission in the rat hippocampus in vitro. Neuroscience 2001 108:83-90.

76. Kanno T, Nagata T, Yamamoto S, Okamura H, Nishizaki T: Interleukin-18 stimulates synaptically released glutamate and enhances postsynaptic AMPA receptor responses in the CA1 region of mouse hippocampal slices. Brain Res 2004, 1012:190-193.

77. Yaguchi T, Nagata T, Yang D, Nishizaki T: Interleukin-18 regulates motor activity, anxiety and spatial learning without affecting synaptic plasticity. Behav Brain Res 2010, 206:47-51.

78. Sugama S, Conti B: Interleukin-18 and stress. Brain Res Rev 2008, 58:85-95.

79. Sekiyama A, Ueda H, Kashiwamura S, Nishida K, Kawai K, Teshima-kondo S, Rokutan K, Okamura H: IL-18; a cytokine translates a stress into medical science. J Med Invest 2005, 52(Suppl):236-239.

80. Nagai Y, Nochi T, Watanabe K, Aso H, Kitazawa H, Matsuzaki M, Ohwada S, Yamaguchi T: Localization of interleukin-18 and its receptor in somatotrophs of the bovine anterior pituitary gland. Cell Tissue Res 2005, 322:455-462

81. Tringali G, Pozzoli G, Vairano M, Mores N, Preziosi P, Navarra P: Interleukin18 displays effects opposite to those of interleukin-1 in the regulation of neuroendocrine stress axis. J Neuroimmunol 2005, 160:61-67.

82. Felderhoff-Mueser U, Schmidt OI, Oberholzer A, Buhrer C, Stahel PF: IL-18: a key player in neuroinflammation and neurodegeneration?. Trends Neurosci 2005, 28:487-493.

83. Abulafia DP, de Rivero Vaccari JP, Lozano JD, Lotocki G, Keane RW, Dietrich WD: Inhibition of the inflammasome complex reduces the inflammatory response after thromboembolic stroke in mice. $J$ Cereb Blood Flow Metab 2009, 29:534-544.

84. Qiu L, Zhu C, Wang X, Xu F, Eriksson PS, Nilsson M, Cooper-Kuhn CM, Kuhn $\mathrm{HG}$, Blomgren $\mathrm{K}$ : Less neurogenesis and inflammation in the immature than in the juvenile brain after cerebral hypoxia-ischemia. J Cereb Blood Flow Metab 2007, 27:785-794.

85. Mori I, Hossain MJ, Takeda K, Okamura H, Imai Y, Kohsaka S, Kimura Y: Impaired microglial activation in the brain of IL-18-gene-disrupted mice after neurovirulent influenza A virus infection. Virology 2001, 287:163-170.

86. Jander S, Schroeter M, Stoll G: Interleukin-18 expression after focal ischemia of the rat brain: association with the late-stage inflammatory response. J Cereb Blood Flow Metab 2002, 22:62-70.

87. de Rivero Vaccari JP, Lotocki G, Marcillo AE, Dietrich WD, Keane RW: A molecular platform in neurons regulates inflammation after spinal cord injury. J Neurosci 2008, 28:3404-3414.

88. Xie WR, Deng H, Li H, Bowen TL, Strong JA, Zhang JM: Robust increase of cutaneous sensitivity, cytokine production and sympathetic sprouting in rats with localized inflammatory irritation of the spinal ganglia. Neuroscience 2006, 142:809-822.

89. Jander S, Stoll G: Differential induction of interleukin-12, interleukin-18, and interleukin-1 beta converting enzyme mRNA in experimental autoimmune encephalomyelitis of the Lewis rat. J Neuroimmunol 1998, 91:93-99.

90. Wildbaum G, Youssef S, Grabie N, Karin N: Neutralizing antibodies to IFNgamma-inducing factor prevent experimental autoimmune encephalomyelitis. J Immunol 1998, 161:6368-6374. 
91. Shi FD, Takeda K, Akira S, Sarvetnick N, Ljunggren HG: IL-18 directs autoreactive $T$ cells and promotes autodestruction in the central nervous system via induction of IFN-gamma by NK cells. J Immunol 2000, 165:3099-3104.

92. Schif-Zuck S, Westermann J, Netzer N, Zohar Y, Meiron M, Wildbaum G, Karin N: Targeted overexpression of IL-18 binding protein at the central nervous system overrides flexibility in functional polarization of antigenspecific Th2 cells. J Immunol 2005, 174:4307-4315.

93. Gutcher I, Urich E, Wolter K, Prinz M, Becher B: Interleukin 18-independent engagement of interleukin 18 receptor-alpha is required for autoimmune inflammation. Nat Immunol 2006, 7:946-953.

94. Thessen Hedreul M, Gillett A, Olsson T, Jagodic M, Harris RA: Characterization of Multiple Sclerosis candidate gene expression kinetics in rat experimental autoimmune encephalomyelitis. J Neuroimmunol 2009, 210:30-39

95. Huang WX, Huang $P$, Hillert J: Increased expression of caspase-1 and interleukin-18 in peripheral blood mononuclear cells in patients with multiple sclerosis. Mult Scler 2004, 10:482-487.

96. Karni A, Koldzic DN, Bharanidharan P, Khoury SJ, Weiner HL: IL-18 is linked to raised IFN-gamma in multiple sclerosis and is induced by activated CD4(+) T cells via CD40-CD40 ligand interactions. J Neuroimmunol 2002, 125:134-140

97. Losy J, Niezgoda A: IL-18 in patients with multiple sclerosis. Acta Neurol Scand 2001, 104:171-173

98. Nicoletti F, Di Marco R, Mangano K, Patti F, Reggio E, Nicoletti A, Bendtzen K, Reggio A: Increased serum levels of interleukin-18 in patients with multiple sclerosis. Neurology 2001, 57:342-344.

99. Balashov KE, Rottman JB, Weiner HL, Hancock WW: CCR5(+) and CXCR3(+) $T$ cells are increased in multiple sclerosis and their ligands MIP-1alpha and IP-10 are expressed in demyelinating brain lesions. Proc Natl Acad Sci USA 1999, 96:6873-6878.

100. Furlan R, Martino G, Galbiati F, Poliani PL, Smiroldo S, Bergami A, Desina G, Comi G, Flavell R, Su MS, Adorini L: Caspase-1 regulates the inflammatory process leading to autoimmune demyelination. J Immunol 1999, 163:2403-2409.

101. Furlan R, Filippi $M$, Bergami $A$, Rocca MA, Martinelli V, Poliani $P L$, Grimaldi LM, Desina G, Comi G, Martino G: Peripheral levels of caspase-1 mRNA correlate with disease activity in patients with multiple sclerosis: a preliminary study. J Neurol Neurosurg Psychiatry 1999, 67:785-788.

102. Olson JK, Girvin AM, Miller SD: Direct activation of innate and antigenpresenting functions of microglia following infection with Theiler's virus. J Virol 2001, 75:9780-9789.

103. Caselli RJ, Beach TG, Yaari R, Reiman EM: Alzheimer's disease a century later. J Clin Psychiatry 2006, 67:1784-1800.

104. Griffin WS: Inflammation and neurodegenerative diseases. Am J Clin Nutr 2006, 83:470S-474S.

105. Aarli JA: Role of cytokines in neurological disorders. Curr Med Chem 2003, 10:1931-1937.

106. Ojala J, Alafuzoff I, Herukka SK, van Groen T, Tanila H, Pirttila T: Expression of interleukin-18 is increased in the brains of Alzheimer's disease patients. Neurobiol Aging 2009, 30:198-209.

107. Malaguarnera L, Motta M, Di Rosa M, Anzaldi M, Malaguarnera M: Interleukin-18 and transforming growth factor-beta 1 plasma levels in Alzheimer's disease and vascular dementia. Neuropathology 2006, 26:307-312.

108. Ozturk C, Ozge A, Yalin OO, Yilmaz IA, Delialioglu N, Yildiz C, Tesdelen B, Kudiaki C: The diagnostic role of serum inflammatory and soluble proteins on dementia subtypes: correlation with cognitive and functional decline. Behav Neurol 2007, 18:207-215.

109. Motta M, Imbesi R, Di Rosa M, Stivala F, Malaguarnera L: Altered plasma cytokine levels in Alzheimer's disease: correlation with the disease progression. Immunol Lett 2007, 114:46-51.

110. Lindberg C, Chromek M, Ahrengart L, Brauner A, Schultzberg M, Garlind A Soluble interleukin-1 receptor type II, IL-18 and caspase-1 in mild cognitive impairment and severe Alzheimer's disease. Neurochem Int 2005, 46:551-557.

111. Bossu P, Ciaramella A, Salani F, Bizzoni F, Varsi E, Di lulio F, Giubilei F, Gianni W, Trequattrini A, Moro ML, et al: Interleukin-18 produced by peripheral blood cells is increased in Alzheimer's disease and correlates with cognitive impairment. Brain Behav Immun 2008, 22:487-492.
112. Di Rosa M, Dell'Ombra N, Zambito AM, Malaguarnera M, Nicoletti F, Malaguarnera L: Chitotriosidase and inflammatory mediator levels in Alzheimer's disease and cerebrovascular dementia. Eur J Neurosci 2006, 23:2648-2656.

113. Yu JT, Tan L, Song JH, Sun YP, Chen W, Miao D, Tian Y: Interleukin-18 promoter polymorphisms and risk of late onset Alzheimer's disease. Brain Res 2009, 1253:169-175.

114. Bossu P, Ciaramella A, Moro ML, Bellincampi L, Bernardini S, Federici G, Trequattrini A, Macciardi F, Spoletini I, Di lulio F, et al: Interleukin 18 gene polymorphisms predict risk and outcome of Alzheimer's disease. J Neurol Neurosurg Psychiatry 2007, 78:807-811.

115. Segat L, Milanese M, Arosio B, Vergani C, Crovella S: Lack of association between Interleukin-18 gene promoter polymorphisms and onset of Alzheimer's disease. Neurobiol Aging 2008, 31:162-164.

116. Iannello A, Samarani S, Debbeche O, Tremblay C, Toma E, Boulassel MR, Routy JP, Ahmad A: Role of interleukin-18 in the development and pathogenesis of AIDS. AIDS Rev 2009, 11:115-125.

117. Sugama S, Wirz SA, Barr AM, Conti B, Bartfai T, Shibasaki T: Interleukin-18 null mice show diminished microglial activation and reduced dopaminergic neuron loss following acute 1-methyl-4-phenyl-1,2,3,6tetrahydropyridine treatment. Neuroscience 2004, 128:451-458.

118. Corcos M, Guilbaud O, Hjalmarsson L, Chambry J, Jeammet P: Cytokines and depression: an analogic approach. Biomed Pharmacother 2002, 56:105-110.

119. Dinan TG: Inflammatory markers in depression. Curr Opin Psychiatry 2009, 22:32-36.

120. Ganguli R, Yang Z, Shurin G, Chengappa KN, Brar JS, Gubbi AV, Rabin BS: Serum interleukin- 6 concentration in schizophrenia: elevation associated with duration of illness. Psychiatry Res 1994, 51:1-10.

121. Licinio J, Wong ML: The role of inflammatory mediators in the biology of major depression: central nervous system cytokines modulate the biological substrate of depressive symptoms, regulate stress-responsive systems, and contribute to neurotoxicity and neuroprotection. $\mathrm{Mol}$ Psychiatry 1999, 4:317-327.

122. Myint AM, Kim YK: Cytokine-serotonin interaction through IDO: a neurodegeneration hypothesis of depression. Med Hypotheses 2003, 61:519-525.

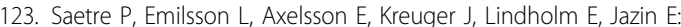
Inflammation-related genes up-regulated in schizophrenia brains. BMC Psychiatry 2007, 7:46.

124. Appels A, Bar FW, Bar J, Bruggeman C, de Baets M: Inflammation, depressive symptomtology, and coronary artery disease. Psychosom Med 2000, 62:601-605.

125. Eisner MD, Katz PP, Lactao G, Iribarren C: Impact of depressive symptoms on adult asthma outcomes. Ann Allergy Asthma Immunol 2005, 94:566-574

126. Muller N, Gizycki-Nienhaus B, Gunther W, Meurer M: Depression as a cerebral manifestation of scleroderma: immunological findings in serum and cerebrospinal fluid. Biol Psychiatry 1992, 31:1151-1156.

127. O'Reilly RL, Singh SM: Retroviruses and schizophrenia revisited. Am J Med Genet 1996, 67:19-24

128. Muller N, Strassnig M, Schwarz MJ, Ulmschneider M, Riedel M: COX-2 inhibitors as adjunctive therapy in schizophrenia. Expert Opin Investig Drugs 2004, 13:1033-1044.

129. Yu YW, Chen TJ, Hong CJ, Chen HM, Tsai SJ: Association study of the interleukin-1 beta (C-511T) genetic polymorphism with major depressive disorder, associated symptomatology, and antidepressant response. Neuropsychopharmacology 2003, 28:1182-1185.

130. Jun TY, Pae CU, Hoon H, Chae JH, Bahk WM, Kim KS, Serretti A: Possible association between -G308A tumour necrosis factor-alpha gene polymorphism and major depressive disorder in the Korean population. Psychiatr Genet 2003, 13:179-181.

131. Behrens MM, Ali SS, Dugan LL: Interleukin-6 mediates the increase in NADPH-oxidase in the ketamine model of schizophrenia. J Neurosci 2008, 28:13957-13966.

132. Bilbo SD, Schwarz JM: Early-life programming of later-life brain and behavior: a critical role for the immune system. Front Behav Neurosci 2009, 3:14.

133. Kroes RA, Panksepp J, Burgdorf J, Otto NJ, Moskal JR: Modeling depression: social dominance-submission gene expression patterns in rat neocortex. Neuroscience 2006, 137:37-49. 
134. Lu LX, Guo SQ, Chen W, Li Q, Cheng J, Guo JH: [Effect of clozapine and risperidone on serum cytokine levels in patients with first-episode paranoid schizophrenia]. Di Yi Jun Yi Da Xue Xue Bao 2004, 24:1251-1254.

135. Tanaka KF, Shintani F, Fujii Y, Yagi G, Asai M: Serum interleukin-18 levels are elevated in schizophrenia. Psychiatry Res 2000, 96:75-80.

136. Kokai M, Kashiwamura S, Okamura H, Ohara K, Morita Y: Plasma interleukin18 levels in patients with psychiatric disorders. J Immunother 2002, 25(Suppl 1):S68-71.

137. Merendino RA, Di Rosa AE, Di Pasquale G, Minciullo PL, Mangraviti C, Costantino A, Ruello A, Gangemi S: Interleukin-18 and CD30 serum levels in patients with moderate-severe depression. Mediators Inflamm 2002, 11:265-267.

138. Spalletta G, Bossu P, Ciaramella A, Bria P, Caltagirone C, Robinson RG: The etiology of poststroke depression: a review of the literature and a new hypothesis involving inflammatory cytokines. Mol Psychiatry 2006, 11:984-991.

139. Bossu P, Salani F, Cacciari C, Picchetto L, Cao M, Bizzoni F, Rasura M, Caltagirone C, Robinson RG, Orzi F, Spalletta G: Disease outcome, alexithymia and depression are differently associated with serum IL-18 levels in acute stroke. Curr Neurovasc Res 2009, 6:163-170.

140. Fang J, Cheng Q: Etiological mechanisms of post-stroke depression: a review. Neurol Res 2009, 31:904-909.

141. Sugama S, Kim Y, Baker H, Tinti C, Kim H, Joh TH, Conti B: Tissue-specific expression of rat IL-18 gene and response to adrenocorticotropic hormone treatment. J Immunol 2000, 165:6287-6292.

142. Sugama S, Wang N, Shimokawa N, Koibuchi N, Fujita M, Hashimoto M, Dhabhar FS, Conti B: The adrenal gland is a source of stress-induced circulating IL-18. J Neuroimmunol 2006, 172:59-65.

143. Sekiyama A, Ueda H, Kashiwamura S, Nishida K, Yamaguchi S, Sasaki H, Kuwano Y, Kawai K, Teshima-Kondo S, Rokutan K, Okamura H: A role of the adrenal gland in stress-induced up-regulation of cytokines in plasma. $J$ Neuroimmunol 2006, 171:38-44.

144. Maes M, Bosmans E, Meltzer HY, Scharpe S, Suy E: Interleukin-1 beta: a putative mediator of HPA axis hyperactivity in major depression?. Am J Psychiatry 1993, 150:1189-1193.

145. Maes M, Scharpe S, Meltzer HY, Bosmans E, Suy E, Calabrese J, Cosyns P: Relationships between interleukin- 6 activity, acute phase proteins, and function of the hypothalamic-pituitary-adrenal axis in severe depression. Psychiatry Res 1993, 49:11-27.

146. Pariante CM, Pearce BD, Pisell TL, Sanchez Cl, Po C, Su C, Miller AH: The proinflammatory cytokine, interleukin-1alpha, reduces glucocorticoid receptor translocation and function. Endocrinology 1999, 140:4359-4366.

147. McKay LI, Cidlowski JA: Molecular control of immune/inflammatory responses: interactions between nuclear factor-kappa $B$ and steroid receptor-signaling pathways. Endocr Rev 1999, 20:435-459.

148. Wang $X$, Wu H, Miller AH: Interleukin 1alpha (IL-1alpha) induced activation of p38 mitogen-activated protein kinase inhibits glucocorticoid receptor function. Mol Psychiatry 2004, 9:65-75.

149. Pariante CM, Lightman SL: The HPA axis in major depression: classical theories and new developments. Trends Neurosci 2008, 31:464-468.

150. Zhang XM, Duan RS, Chen Z, Quezada HC, Mix E, Winblad B, Zhu J: IL-18 deficiency aggravates kainic acid-induced hippocampal neurodegeneration in C57BL/6 mice due to an overcompensation by IL12. Exp Neurol 2007, 205:64-73.

151. Sarin H: Recent progress towards development of effective systemic chemotherapy for the treatment of malignant brain tumors. J Trans/ Med 2009, 7:77.

152. Kito T, Kuroda E, Yokota A, Yamashita U: Cytotoxicity in glioma cells due to interleukin-12 and interleukin-18-stimulated macrophages mediated by interferon-gamma-regulated nitric oxide. J Neurosurg 2003, 98:385-392.

153. Kikuchi T, Akasaki $Y$, Joki T, Abe T, Kurimoto M, Ohno T: Antitumor activity of interleukin-18 on mouse glioma cells. J Immunother 2000, 23:184-189.

154. Yamanaka R, Tsuchiya N, Yajima N, Honma J, Hasegawa H, Tanaka R, Ramsey J, Blaese RM, Xanthopoulos KG: Induction of an antitumor immunological response by an intratumoral injection of dendritic cells pulsed with genetically engineered Semliki Forest virus to produce interleukin-18 combined with the systemic administration of interleukin12. J Neurosurg 2003, 99:746-753.

155. Yamanaka R, Yajima N, Tsuchiya N, Honma J, Tanaka R, Ramsey J, Blaese M, Xanthopoulos KG: Administration of interleukin-12 and -18 enhancing the antitumor immunity of genetically modified dendritic cells that had been pulsed with Semliki forest virus-mediated tumor complementary DNA. J Neurosurg 2002, 97:1184-1190.

156. Zhang Y, Wang C, Sun M: C6 glioma cells retrovirally engineered to express IL-18 and Fas exert FasL-dependent cytotoxicity against glioma formation. Biochem Biophys Res Commun 2004, 325:1240-1245.

157. Xu G, Jiang XD, Xu Y, Zhang J, Huang FH, Chen ZZ, Zhou DX, Shang JH, Zou YX, Cai YQ, et al: Adenoviral-mediated interleukin-18 expression in mesenchymal stem cells effectively suppresses the growth of glioma in rats. Cell Biol Int 2009, 33:466-474.

158. Matsui K, Yoshimoto T, Tsutsui H, Hyodo Y, Hayashi N, Hiroishi K, Kawada N, Okamura $\mathrm{H}$, Nakanishi K, Higashino K: Propionibacterium acnes treatment diminishes CD4+ NK1.1+ T cells but induces type I T cells in the liver by induction of IL-12 and IL-18 production from Kupffer cells. J Immunol 1997, 159:97-106.

159. Stoll S, Muller G, Kurimoto M, Saloga J, Tanimoto T, Yamauchi $H$, Okamura H, Knop J, Enk AH: Production of IL-18 (IFN-gamma-inducing factor) messenger RNA and functional protein by murine keratinocytes. $J$ Immunol 1997, 159:298-302.

160. Liu YP, Lin HI, Tzeng SF: Tumor necrosis factor-alpha and interleukin-18 modulate neuronal cell fate in embryonic neural progenitor culture. Brain Res 2005, 1054:152-158.

161. Johansson CB, Momma S, Clarke DL, Risling M, Lendahl U, Frisen J: Identification of a neural stem cell in the adult mammalian central nervous system. Cell 1999, 96:25-34.

162. Li S, Goorha S, Ballou LR, Blatteis CM: Intracerebroventricular interleukin-6, macrophage inflammatory protein-1 beta and IL-18: pyrogenic and PGE (2)-mediated?. Brain Res 2003, 992:76-84.

163. Kumar RA, Cann C, Hall JE, Sudheer PS, Wilkes AR: Predictive value of IL-18 and SC5b-9 for neurocognitive dysfunction after cardiopulmonary bypass. Br J Anaesth 2007, 98:317-322.

164. Yatsiv I, Morganti-Kossmann MC, Perez D, Dinarello CA, Novick D, Rubinstein M, Otto Vl, Rancan M, Kossmann T, Redaelli CA, et al: Elevated intracranial IL-18 in humans and mice after traumatic brain injury and evidence of neuroprotective effects of IL-18-binding protein after experimental closed head injury. J Cereb Blood Flow Metab 2002, 22:971-978.

165. Hedtjarn M, Mallard C, Arvidsson P, Hagberg $H$ : White matter injury in the immature brain: role of interleukin-18. Neurosci Lett 2005, 373:16-20.

166. Hedtjarn M, Mallard C, Iwakura Y, Hagberg H: Combined deficiency of IL1 beta18, but not IL-1alphabeta, reduces susceptibility to hypoxiaischemia in the immature brain. Dev Neurosci 2005, 27:143-148.

167. Zhu C, Qiu L, Wang X, Xu F, Nilsson M, Cooper-Kuhn C, Kuhn HG, Blomgren $\mathrm{K}$ : Age-dependent regenerative responses in the striatum and cortex after hypoxia-ischemia. J Cereb Blood Flow Metab 2009, 29:342-354

168. Fukui O, Kinugasa Y, Fukuda A, Fukuda H, Tskitishvili E, Hayashi S, Song M, Kanagawa T, Hosono T, Shimoya K, Murata Y: Post-ischemic hypothermia reduced IL-18 expression and suppressed microglial activation in the immature brain. Brain Res 2006, 1121:35-45.

169. Zaremba J, Losy J: Interleukin-18 in acute ischaemic stroke patients. Neurol Sci 2003, 24:117-124.

170. Abdul-Careem MF, Hunter BD, Sarson AJ, Mayameei A, Zhou H, Sharif S: Marek's disease virus-induced transient paralysis is associated with cytokine gene expression in the nervous system. Viral Immunol 2006, 19:167-176.

171. von Giesen HJ, Jander S, Koller H, Arendt G: Serum and cerebrospinal fluid levels of interleukin-18 in human immunodeficiency virus type 1associated central nervous system disease. J Neurovirol 2004, 10:383-386.

doi:10.1186/1742-2094-7-9

Cite this article as: Alboni et al:: Interleukin 18 in the CNS. Journal of Neuroinflammation 2010 7:9. 